\title{
Teaching Film in New Normal Era at Film Department, Universitas Multimedia Nusantara
}

\author{
Annita \\ Universitas Multimedia Nusantara, Jl. Scientia Boulevard, Gading Serpong, Tangerang, Banten- \\ 15811 Indonesia \\ E-mail: annita@umn.ac.id
}

\begin{abstract}
COVID-19 has forced many people to adjust to the new situation. The Indonesian education system has been changed drastically because of this pandemic. Although online learning differs from traditional class meetings, most academic institutions switch directly to online without necessary adjustments. As a result, many students experience zoom fatigue. The same thing also happened in the writer's university. Thus, adjustment toward the teaching-learning strategies is needed to avoid this exhaustion. In this research, the writer applied asynchronous learning in one of the film courses. The asynchronous was applied in ten meetings uploaded on the university's online platform. At the end of the semester, a survey was conducted to evaluate the method. This research is aimed to explore other possible methods in teaching film. It is necessary because teaching film requires a lot of physical and social interaction, which is impossible during this era.
\end{abstract}

Keywords: adjustment, teaching film, asynchronous

\section{Pengajaran Film Pada Era Kenormalan Baru di Prodi Film Universitas Multimedia Nusantara}

ABSTRAK

COVID-19 telah membuat sistem pendidikan Indonesia berubah secara drastis. Sebagian besar institusi akademik beralih langsung ke pembelajaran daring, tanpa membuat penyesuaian dengan media daring yang memiliki karakteristik sangat berbeda dari pembelajaran tatap muka di kelas. Akibatnya, banyak siswa yang mengalami kelelahan karena tatap muka daring. Hal yang sama juga terjadi di universitas penulis. Oleh karena itu, penyesuaian terhadap strategi belajarmengajar diperlukan untuk menghindari kelelahan ini. Dalam penelitian ini penulis menerapkan pembelajaran asinkron di salah satu mata kuliah film. Pembelajaran asinkron diterapkan pada sepuluh pertemuan yang diunggah ke media daring milik universitas. Pada akhir semester dilakukan survei untuk mengevaluasi metode tersebut. Penelitian ini bertujuan untuk mengeksplorasi metode lain yang mungkin digunakan dalam pengajaran film. Hal ini diperlukan karena pengajaran film membutuhkan banyak interaksi fisik dan sosial, yang tidak mungkin dilakukan pada era ini.

Kata kunci: adaptasi, pengajaran film, pembelajaran asinkron

\section{INTRODUCTION}

Since the Covid-19 outbreaks in January 2020, people worldwide have been forced to adapt to a new way of living. This virus has impacted every aspect of the human being, including education. Schools and universities are closed and migrate from 
traditional face-to-face learning to online learning (Bao, 2020; Rajhans et al., 2020; UNESCO, 2020). For institutions that have integrated online learning in their system, this change may not have sudden impacts. However, for the majority of schools in Indonesia, the conversion has shaken the pedagogical framework. Many teachers are not prepared and equipped with facilities, skills, and knowledge in online teaching (Moralista and Oducado, 2020; The Conversation 2020).

Online teaching is not just about altering the medium. It is also about course design (Anggrainingsih et al. 2018; Noorulhasan et al. 2017), technical skill to use learning management system/LMS (El-Gawad and Woollard, 2019), and understanding of how learners learn in an online environment (Alqahtani and Rajkhan, 2020; Bani-Salameh and Fakher, 2015; Martin et al., 2019). Instructors in online learning need to change their roles in teaching from "teacher-centered to student-centered, low-interactor to high-interactor, and low-initiator to highinitiator" (Beck and Ferdig, 2008). Martin et al. summarize the roles and responsibility of online instructors into five parts as follow:

1. Facilitator: supports the learners during their online session. For example: consistently checking in with students, communicate both in synchronous and asynchronous, and encourage students to participate and complete the tasks.

2. Course designer: focuses on the connection between learning results, assessments, and teaching activities. S/he must make sure the relationship between those elements is aligned with the content and delivery approach. Depending on the institution's support, this role may be done by a collaborative team and prepared earlier before the course begins.

3. Course manager: concentrates on dealing with content and assessing students' learning.

4. Subject matter expert: substantiates expertise on content.

5. Mentor: advises students' academic and professional development (Martin et al., 2019).

Online learning has two types: synchronous and asynchronous. In synchronous, teachers and students are involved in real-time online learning. Whereas in asynchronous, online learning does not happen in real-time (Hafner and Ellis, 2004; Jasim Mohammed et al., 2018; Young et al., 2014; Alqahtani and Rajkhan, 2020; Van Der Molen, 2016). 


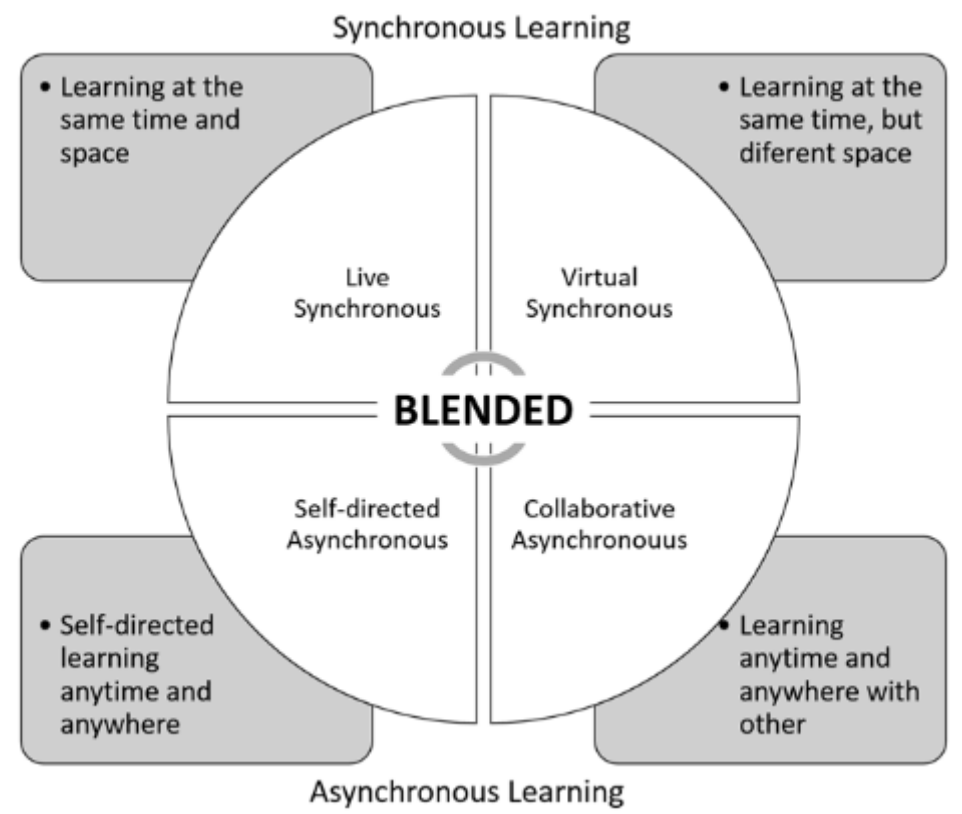

Figure 1. Quadrant of Blended Learning Setting Source: Chaeruman et al., 2018

Chaeruman et al., give examples of activities for each category above as follow (Chaeruman et al., 2018):

Table 1. Example of Learning Activities (Chaeruman et al., 2018)

\begin{tabular}{|c|c|c|}
\hline No & Types & Activities \\
\hline 1. & Live synchronous & $\begin{array}{l}\text { lecture, group discussion, lab } \\
\text { practice, etc. }\end{array}$ \\
\hline 2. & Virtual synchronous & audio and/or video conference. \\
\hline 3. & Collaborative asynchronous & $\begin{array}{l}\text { Discussion forum, online assignment, } \\
\text { etc. }\end{array}$ \\
\hline 4. & Self-directed asynchronous & $\begin{array}{l}\text { learning objects in the form of text, } \\
\text { audio-visual, simulation, etc. }\end{array}$ \\
\hline
\end{tabular}

This paper aims to explore other possible methods in teaching film during the university's lockdown due to Covid-19. The adjustment is applied in FF561 Image and Sound Concept at the Film Department, Universitas Multimedia Nusantara. In this course, students have to formulate images and sound concepts for their films. This film is going to be their final project as a requirement to graduate from the university. The writer collaborates with the E-learning team of Universitas Multimedia Nusantara to create asynchronous materials for the course. Asynchronous teaching is chosen to reduce students' fatigue toward online 
synchronous teaching. This is a trial project since it is applied in a course that combines both theory and practice. Similar asynchronous projects have been applied in theory-based courses. The research is aimed to create alternative teaching methods, especially for practice-based courses during online learning.

\section{MATERIALS AND METHOD}

The preparation for this research had been done since January 2020. The teaching team collaborated with the E-learning team to prepare online materials for the course, FF561 Image and Sound Concept. The roles of both parties follow Martin et al., description of online instructors. The teaching team acted as facilitator, course manager, subject matter expert, and mentor. At the same time, the E-learning team acted as a course designer.

The teaching team prepared video materials, slides, quizzes, discussion topics, and assignments. The E-learning team was in charge of editing videos, applying interactive tools, uploading to the LMS, and duplicating other parallel classes. There were five classes with a total of 162 students. The materials were divided into four categories: slide, teaching video, quiz, forum, and assignment.

Table 2. Designed materials for FF561

\begin{tabular}{|c|c|c|}
\hline No. & Categories & Description \\
\hline 1. & Slide & Teaching materials in the form of Pdf. \\
\hline 2. & Video & $\begin{array}{l}\text { Each video is } 8-10 \text { minutes in length. For each } \\
\text { meeting, it may have } 1 \text { to } 3 \text { videos depending on } \\
\text { the complexity of the topic. }\end{array}$ \\
\hline 3. & Quiz & $\begin{array}{l}\text { The quiz usually consists of } 10-15 \text { true-false or } \\
\text { multiple-choice questions. }\end{array}$ \\
\hline 4. & Forum & $\begin{array}{l}\text { It is a discussion forum. Students and the lecturer } \\
\text { discuss questions/issues related to the topic. }\end{array}$ \\
\hline 5. & Assignment & $\begin{array}{l}\text { It is a project (paper, student video presentation, } \\
\text { etc.) submitted in one or two weeks after the task } \\
\text { is given. }\end{array}$ \\
\hline
\end{tabular}

These descriptions follow the blended learning scheme of PEDATI (Chaeruman 2017), which consists of:

1. PElajari (learn): through slides and videos

2. DAlami (comprehend): through an online discussion forum

3. Terapkan (apply): through an assignment

4. EvaluasI (evaluate): through a quiz

The research was conducted from the third week of February to May 2020. Initially, the course was designed with four face-to-face meetings and ten blended learning 
activities. However, in March, the university was closed due to Covid-19 outbreaks. Thus, some adjustment was made to fit the scenario. The face-to-face meeting, group discussion, and student-teacher consultation were replaced with online meetings using Zoom. At the end of the semester, students were asked to fill in a survey to evaluate the course. The items asked were as follow:

1. 5-point Likert scale questions about lecturer's teaching competencies, including clarity in teaching, the pace of delivering materials, interactivity, time for discussion, assistance to help students, and fairness in grading.

2. 5-point Likert scale questions about materials given during online sessions, which include relevance to course objectives and syllabus, preparation of materials, balance of course assignment to course credit, appropriateness of class activities to course objectives, and students' participation in-class activities.

3. Yes/no/other-response type question about whether the shifting from offline to online worked well.

4. Multiple choice questions about the choice of learning during university's closure: synchronous (online meeting) or blended learning( 4 online meetings +10 asynchronous activities).

5. An open-ended question about students' suggestions toward the course.

\section{RESULTS}

Among 162 students who enrolled in the course, only 53 students participated in the questionnaire. The result of the questionnaire is as follow:

1. Lecturer's teaching competences

a. Clarity in teaching

Sixteen students strongly agreed that the lecturer delivered the materials clearly in synchronous and asynchronous meetings. Twenty-three students agreed that the lecturer delivered the materials. Seven students answered neutrally. Four students disagreed, and three students strongly disagreed with the statement that the lecturer delivered the materials clearly in synchronous and asynchronous meetings.

b. The pace of delivering materials

Fifteen students strongly agreed that the lecturer taught at an appropriate pace in synchronous and asynchronous settings. Twenty-two students agreed to the idea. Fourteen students were neutral. None disagreed, and two students strongly disagreed that the lecturer taught with appropriate pace in synchronous and asynchronous settings. 
c. Interactivity

Fourteen students strongly agreed that the lecturer taught the course interactively, both in synchronous and asynchronous sessions. Twenty-three students agreed the lecturer taught interactively. Eleven were neutral. Three students disagreed, and two students strongly disagreed with the idea that the lecturer taught the course interactively.

d. Time for discussion

Seventeen students strongly agreed that the lecturer gave them enough time for discussion. There were twenty-three who agreed to the statement. Ten students were neutral. None disagreed, and three strongly disagreed that the lecturer gave them enough time for discussion.

e. Assistance to help students

Twelve students strongly agreed that lecturer helped students when they were confused or had questions. Twenty-one students agreed to the statement. Twelve were neutral. Five disagreed, and three students strongly disagreed that the lecturer helped them when they were confused or had questions.

f. Fairness in grading Eleven students strongly agreed that the lecturer gave fair and clear grading. Twenty-five students agreed to the statement. Eleven students neither agreed nor disagreed. Three students disagreed, and three other students strongly disagreed that the lecturer gave fair and clear grading.

2. Materials gave during the online session

a. Relevance to course objectives and syllabus

Fifteen students strongly agreed, and twenty-seven students agreed that the materials given were relevant to the course objectives and syllabus. Nine students were neutral. One student disagreed and strongly disagreed that the materials given were relevant to the course objectives and syllabus.

b. Preparation of materials

Seventeen students strongly agreed that online materials were well prepared. Twenty-six students agreed to the statement as well. Eight students neither agreed nor disagreed. One student disagreed, and one strongly disagreed that the online materials were well prepared.

c. Balance of course assignment to course credit

Fifteen students strongly agreed, and twenty-three agreed that a load, of course, assignment fitted the course credit. Nine students were neutral. Five disagreed, and one strongly disagreed that a load of course assignment fitted the course credit.

d. Appropriateness class activities to course objectives 
Thirteen students strongly agreed that the class activities were designed to meet course objectives. Twenty-four students agreed to the statement. Eleven students were neutral. The remaining five disagreed with the statement.

e. Students' participation in-class activities

Twelve students strongly agreed, and 24 agreed that the activities were designed to participate in every exercise actively. Twelve students neither agreed nor disagreed with the statement. Four disagreed, and one strongly disagreed that the activities were designed to make students participate actively.

3. The shifting from offline to online

In this question, students were asked whether the shifting from offline to online went well. Forty-two students answered yes. Five students answered no. Four students mentioned that they did not find any significant difference because they were accustomed to asynchronous learning. Two students mentioned that the portions between synchronous and asynchronous were not balanced.

4. The choice of learning during the university's closure.

In this question, students were asked whether they prefer synchronous or asynchronous learning. Forty-one students prefer asynchronous learning, whereas the remaining twelve prefer synchronous learning.

5. Students' suggestions toward the course

There were several suggestions for this course. Some students suggested making the grading and attendance systems more lenient since the attendance required completing all assignments for each meeting. Some preferred to get more reminders about the upcoming assignments. Others suggested that the lecturer give comments to their work faster and involve more in the discussions.

\section{DISCUSSION}

FF561 Image and Sound Concept is designed as a course that prepares students before their Final Project. In this course, students prepared the film concept they would make in the following semester - the course combined theory, group work, and discussion to formulate ideas into visible projects. The course was originally designed for a traditional face-to-face meeting. Since the university encouraged all departments to integrate more blended learning, this course was later offered as an experiment by the Film Department. This decision turned out to be a blessing in disguise because the Covid-19 outbreaks later forced the university to close and migrate all learning activities online.

The course was first designed to have four face-to-face meetings and ten blended learning, which combined videos, quizzes, assignments, and online discussions. Two face-to-face meetings were in the first and second meetings, and 
the remaining two were in the last two meetings. Each blended learning was designed to start with the slides of materials that students had to read. After that, students must watch lecturing videos (1-3 videos depending on the topic's complexity), followed by a quiz.

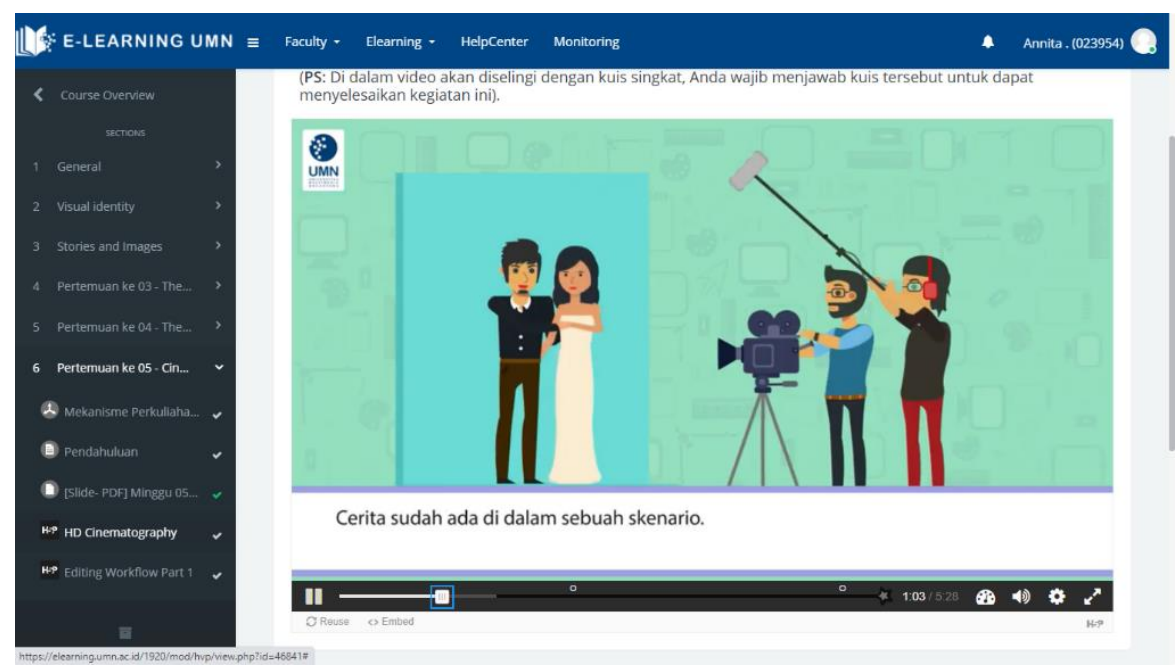

Figure 2. Example of the video in FF561 Image and Sound Concept Source: https://elearning.umn.ac.id/1920/course/view.php?id=3855, Aug 15, 2020

Finished with the quiz, students must participate in an online discussion forum. They must give opinions, ask questions, or respond to their peers' comments related to the topic discussed. In the end, students had to submit an assignment. It might be in the form of a progress report of their project, analysis of similar reference films, etc., which they had to submit within a week. Once the students completed all blended learning activities, the LMS would record the students' attendance for the particular session.

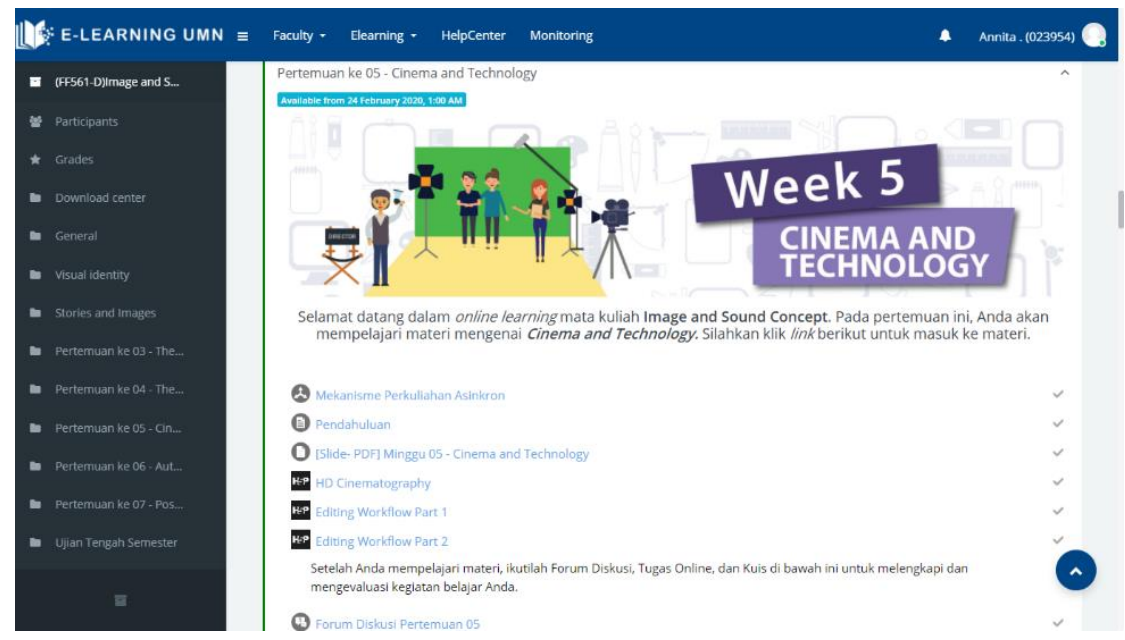

Figure 3. The example of blended learning in FF561 Image and Sound Concept Source: https://elearning.umn.ac.id/1920/course/view.php?id=3855, Aug 15, 2020 
The activity scheme follows the example of learning activities from Chaeruman, et al.: collaborative and self-directed asynchronous in the form of lecture video, online assignment, and quiz (Chaeruman et al. 2018). Live synchronous was applied in the last two meetings as a replacement for the class meeting due to the university its lockdown. Based on the questionnaire's result, $90.5 \%$ of students mentioned that shifting from offline to online went well. The elearning system and well supported the migration from offline to online. This confirms Moralista and Oducado that to migrate smoothly, the schools and teachers must be equipped with facilities, skills, and online teaching knowledge (Moralista and Oducado 2020).

From the questionnaire at the end of the semester, it may be concluded that the majority of students seem to be adjusting well to the online scheme. Students can still get the knowledge, although they have to switch to an online setting. In general, students can cope with the deliverance of materials, clarity of the subjects, assignments to be completed, and access to the lecturer. On the other hand, there are issues related to the lack of human interaction (physical group work, discussion with the lecturer, etc.) and limited exercises students can get to make a film.

The E-learning team supports the integration of blended learning in this course. This division provides technical guidance, rules, and strict supervision for every material the teaching team delivers. The E-learning team makes sure that the blended learning produced to follow the guidelines from PEDATI (Chaeruman 2017). As mentioned by Martin et al., this division has been a great help in technical matters; thus, lecturers may concentrate on the content as subject matter experts.

In terms of content, adjustment toward online learning is quite challenging. This is because of the nature of the film education itself. Film education at Universitas Multimedia Nusantara requires both theory and practice to produce films. Students can not learn just from literature or watching films. To be a filmmaker, they have to make films. Although it uses an online setting in a normal situation, students can still gather and shoot their films. However, this is quite hard in the new normal era because of social and physical distancing.

The adjustments that are made in FF561 Image and Sound Concept to answer this problem are:

1. Postpone all the social activities until it is "safe" to do the shooting. This provides more time for students to prepare their projects. The course serves as a means to guarantee the quality of students' concept for their film and prepare the production so the shooting, later on, can be done effectively. However, the postponement may delay students to graduate on time.

2. Collaborate with animation students to create the film. Instead of making a full live-action film, students may use animation to visualize their ideas. 
This might take a long time since the timeline for animation production is longer than live-action shooting.

3. Adjust the concept of the film to the new normal setting. This enables students to experiment with creative ideas like vertical-video film or collaborative online shooting. An example of this experiment is a short film entitled "Cerita Tentang Jendela" produced by Studio Antelope. This film collaborated shots gathered from their followers and created them into a story. The shots are about various perspectives of the lockdown situation from people's windows.

\section{CONCLUSION}

The new normal era is a very challenging time for all people around the world. Social and physical distancing makes it hard to do whatever that we usually do in a normal setting. However, changes should be made to survive this period. In education, migration to online learning needs to be done. Blended learning can be an option. Integrating learning videos, texts, quizzes, and assignments in an LMS provides students with a learning solution. Students can access and learn the course anytime, anywhere.

Covid-19 may be a challenge for education, but it may prompt educators to develop creative ideas to cope with this problematic situation. Examples mentioned above are the emergence of vertical videos and the collaborative shots woven to create a film. For further research, blended learning effectiveness in practice-based courses can be analyzed since many research available nowadays focus more on theory-based courses. Another topic that can be explored is new creative ways of teaching and learning. Physical distancing may cause people to be socially secluded. However, enhanced virtual appearance like a 3d-moving hologram might create the existence and proximity that is lacked today.

\section{REFERENCES}

\section{Journal}

Alqahtani, A. Y., \& Rajkhan, A. A. (2020). E-learning critical success factors during the covid-19 pandemic: A comprehensive analysis of e-learning managerial perspectives. Education Sciences, 10(9), 1-16. https://doi.org/10.3390/educsci10090216

Anggrainingsih, R., Umam, M. Z., \& Setiadi, H. (2018). Determining e-learning success factor in higher education based on user perspective using Fuzzy AHP. MATEC Web of Conferences, 154, 0-5. https://doi.org/10.1051/matecconf/201815403011

Bani-Salameh, H., \& Fakher, S. A. (2015). E-learning critical success factors 
model: Empirical investigation. ACM International Conference Proceeding Series, 23-25-November-2015(November 2015). https://doi.org/10.1145/2816839.2816870

Bao, W. (2020). COVID -19 and online teaching in higher education: A case study of Peking University. Human Behavior and Emerging Technologies, 2(2), 113-115. https://doi.org/10.1002/hbe2.191

Beck, D., \& Ferdig, R. E. (2008). Evolving roles of online and face-to-face instructors in a lecture/lab hybrid course. In The Turkish Online Journal of Educational Technology (Vol. 7). http://www.websters-onlinedictionary.org/definition/initiate

Chaeruman, U., Wibawa, B., \& Syahrial, Z. (2018). Determining the Appropriate Blend of Blended Learning: A Formative Research in the Context of SpadaIndonesia. American Journal of Educational Research, 6(3), 188-195. https://doi.org/10.12691/education-6-3-5

El-Gawad, T. A., \& Woollard, J. (2013). Critical success factors for implementing e-learning systems in the Egyptian higher education. Computers and Education, December 2019.

Hafner, W., \& Ellis, T. J. (2004). Asynchronous collaborative learning using project-based assignments. Proceedings - Frontiers in Education Conference, FIE, 2. https://doi.org/10.1109/fie.2004.1408607

Martin, F., Budhrani, K., Kumar, S., \& Ritzhaupt, A. (2019). Award-winning faculty online teaching practices: Roles and competencies. Online Learning Journal, 23(1), 184-205. https://doi.org/10.24059/olj.v23i1.1329

Mohammed, H. J., Kasim, M. M., \& Shaharanee, I. N. M. (2018). Evaluation of ELearning Approaches Using AHP-TOPSIS Technique Multi-criteria decision making (MCDM) model View project Data Crawling for Entrepreneurial View project Evaluation of E-Learning Approaches Using AHP-TOPSIS

Technique. https://www.researchgate.net/publication/325390877

Moralista, R., \& Oducado, R. M. F. (2020). Faculty Perception Toward Online Education in Higher Education During the Coronavirus Disease 19 (COVID-19) Pandemic. Universal Journal of Educational Research, 8(10), 4736-4742. https://doi.org/10.31219/osf.io/nhr7b

Noorulhasan, Q., Muhammad, A., Sanober, S., Rafik, M., \& Shah, A. (2017). A Mixed-Method Study for Investigating Critical Success Factors (CSFs) of E-Learning in Saudi Arabian Universities. International Journal of Advanced Computer Science and Applications, 8(5). https://doi.org/10.14569/ijacsa.2017.080522

Rajhans, V., Memon, U., Patil, V., \& Goyal, A. (2020). Impact of COVID-19 on academic activities and way forward in Indian Optometry. Journal of Optometry, 13(4), 216-226. https://doi.org/10.1016/j.optom.2020.06.002

Van Der Molen, J. (2016). Synchronous learning in an asynchronous learning environment. https://www.researchgate.net/publication/299631079

Young, T. P., Bailey, C. J., Guptill, M., Thorp, A. W., \& Thomas, T. L. (2014). The flipped classroom: A modality for mixed asynchronous and asynchronous learning in a residency program. Western Journal of Emergency Medicine, 
Annita, Teaching Film in New Normal Era at Film..

15(7), 938-944. https://doi.org/10.5811/westjem.2014.10.23515

\section{Book}

Chaeruman, U. A. (2017). PEDATI Model Desain Sistem Pembelajaran Blended.

\section{Website / Webtography}

The Conversation. Riset Dampak COVID-19: Potret Gap Akses Online 'Belajar Dari Rumah' Dari 4 Provinsi. 2020, https://theconversation.com/risetdampak-covid-19-potret-gap-akses-online-belajar-dari-rumah-dari-4provinsi-136534.

UNESCO. Education: From Disruption to Recovery. 2020, https://en.unesco.org/covid19/educationresponse. 